\title{
VACUUM HIGH-TEMPERATURE REFINING OF CARBON MATERIALS USING NaCI VAPORS AS A TRANSPORT AND REACTION MEDIUM
}

\author{
Ya.V. Kravtsov, I.V. Gurin, A.N. Bukolov, Yu.A. Gribanov, V.V. Kolosenko \\ National Science Center "Kharkov Institute of Physics and Technology", \\ Kharkiv, Ukraine \\ E-mail: igor@kipt.kharkov.ua; tel./fax+38(057)335-39-83
}

\begin{abstract}
One of the main requirements to carbon materials is their purity. The authors have proposed and experimentally tested a new method for vacuum-thermal refining of carbon materials using $\mathrm{NaCl}$ vapor as an activator. It is experimentally confirmed that this method allows increasing the refining process efficiency and decreasing the energy consumption. The proposed method can be an alternative to modern methods of chlorine- and fluorine thermal refining that permits to exclude the use of hazardous reagents.
\end{abstract}

PACS 620.22

\section{INTRODUCTION}

Currently, carbon materials are widely used for structural parts of modern and projected thermonuclear plants [1], in engineering, rocket and space technology. One of the important requirements to such materials is their purity [2].

Several basic refining methods are applied to produce high-purity carbon materials: chlorine-thermal, fluorine-thermal, high-temperature and vacuum-thermal refining. All of these methods have some disadvantages. For example, in the case of using the fluorine or chlorine refining there are problems of ensuring the safety of processes, as well as an insufficient corrosion resistance of the equipment. The high-temperature refining has a low energy efficiency of the process. A technology drawback of the vacuum-thermal refining is a low resistance of heaters at high operating temperatures.

One of the proposed refining methods can be the technology based on the principles described in the monograph [3]. The paper considers the problems of reaction surface activation in the high-temperature vacuum doping processes with the presence of dissociating activators in the reaction medium. The authors have chosen sodium chloride as the most available activator.

Of some interest is the study of the dissociating activator influence on the process of vacuum-thermal refining of carbon materials. Due to its positive effect on the refining process a possibility may be of excluding the use of toxic substances, decreasing operating temperatures, reducing energy costs of the refining process and increasing the life of heaters.

\section{EXPERIMENTAL PART}

To study the refining process we have used a pyrolysis reactor AGAT 2.0 with the process equipment shown in Fig. 1.

The essence of the method is that in the process of vacuum-thermal refining the $\mathrm{NaCl}$ vapor flow passes through graphite powder and subjects it to dissociating activation. To implement this method, the process equipment has been assembled (see Fig. 1), including container 7 with graphite powder GAK-1, distance spacer 13, container-vaporizer with $\mathrm{NaCl}$ heated by heater 6 . For the purpose of forming a directed $\mathrm{NaCl}$ vapor flow, elements of the technological rig are made of low-porous MPG-7 graphite, and in the bottoms of container 7 and spacer 13 are perforated. At the same time, the container containing $\mathrm{NaCl}$ is partially removed from the heating area, so that the salt would be not overheat and evaporated intensively. The cross-section, the height of the heater support have been chosen so that after reaching a required temperature of $2000{ }^{\circ} \mathrm{C}$ in the region of the container with GAK-1, the temperature on the surface of the container with $\mathrm{NaCl}$ would be not higher than $900{ }^{\circ} \mathrm{C}$. (At this temperature, the salt is melting and evaporates with an acceptable intensity). The temperature in the container region with GAK-1 powder is controlled by a pyrometer, and on the surface of the container a NaCl-XA thermocouple is used.

Thus, after reaching a required temperature, the container with GAK-1 graphite powder evaporates $\mathrm{NaCl}$ and the flow of $\mathrm{NaCl}$ vapors, passing through the GAK-1 graphite powder, interacts with it.

To study the efficiency of the method, a series of experiments were carried out: 1) vacuum-thermal refining; 2) vacuum-thermal refining with $\mathrm{NaCl}$ activator.

Vacuum-thermal refining was carried out at temperatures of about $2000{ }^{\circ} \mathrm{C}$. During the activation refining process, the temperature on the container was maintained at the level of $1800 \ldots 1850{ }^{\circ} \mathrm{C}$.

A material to be refined is natural coarse-grained GAK-1 graphite with a stable content of impurities. An elemental composition of GAK-2 graphite impurities is given in Table 1.

Table 1

Elemental composition of GAK-2 graphite impurities

\begin{tabular}{|c|c|c|c|c|c|}
\hline $\mathrm{Si}$ & $\mathrm{Ca}$ & $\mathrm{Fe}$ & $\mathrm{Cr}$ & $\mathrm{Cu}$ & $\mathrm{S}$ \\
\hline 13.33 & 8.26 & 34.17 & 9.76 & 4.13 & 27.48 \\
\hline
\end{tabular}

The temperature of $1850{ }^{\circ} \mathrm{C}$ has been chosen as an acceptable average refining temperature, the temperature of the container with salt does not exceed $900{ }^{\circ} \mathrm{C}$ that provides a stable $\mathrm{NaCl}$ vapor flow through the graphite powder layer. 


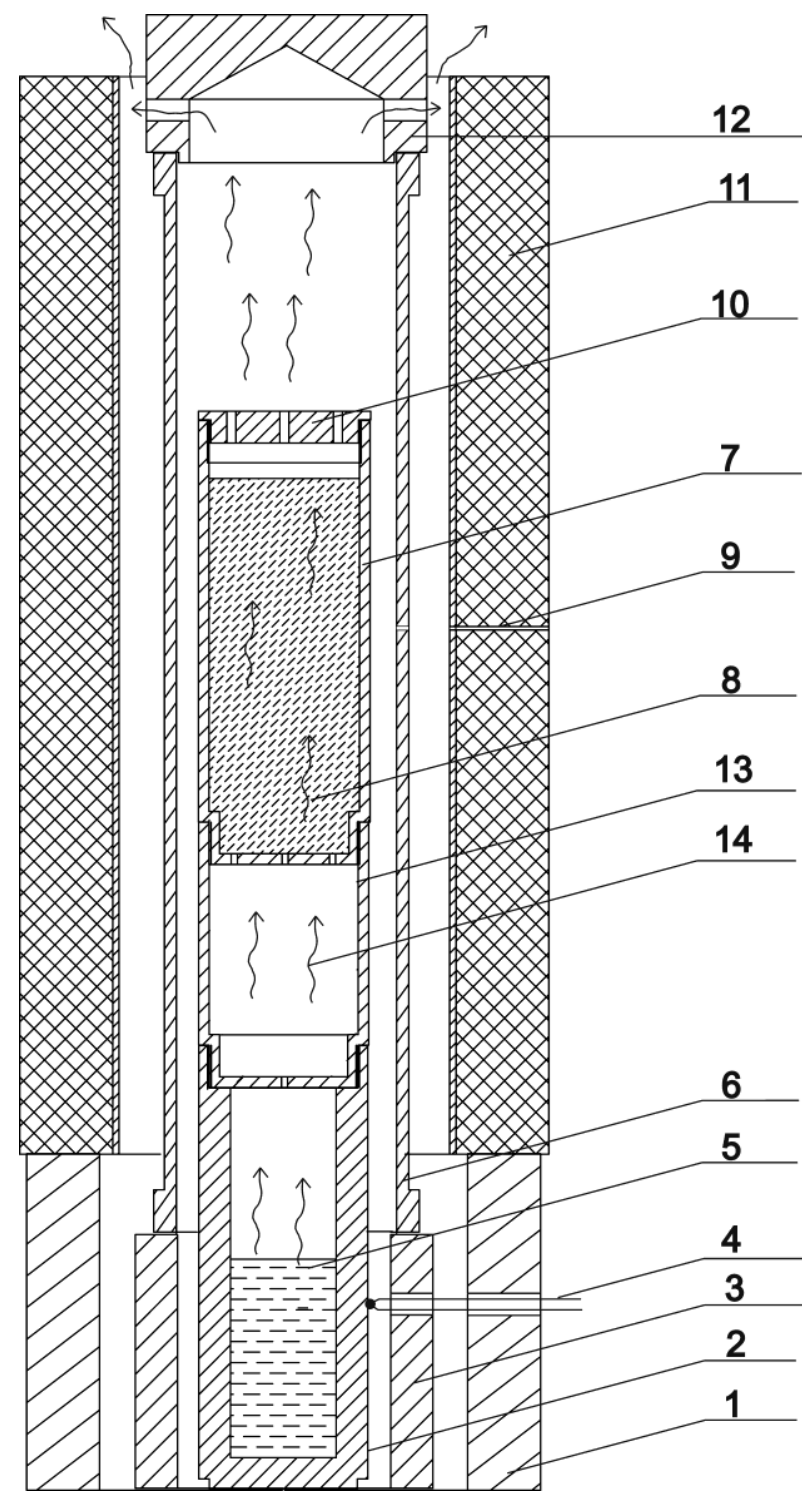

Fig. 1. Diagram of the assembly for $\mathrm{NaCl}$ vaporization and graphite heating: 1 - thermal shield support;

2 - NaCl vaporizer-container; 3 - heater rack;

4 -thermocouple; 5 - NaCl melt; 6 - heater;

7 - refining container; 8 - graphite to be refined;

9 - hole to measure the temperature with a pyrometer;

10 - lid with holes for vapor output; 11 - thermal

shield; 12 - heater cover with holes for vapor output;

$$
13 \text { - spacer; } 14 \text { - NaCl vapors }
$$

The interaction with impurities occurs by the mechanism described in $[4,5]$. The molecule of sodium chloride in the gas phase does not dissociate, it is expected that the complex process of chemical interaction in the $\mathrm{NaCl}$-impurity system occurs by the way of $\mathrm{NaCl}$ molecule adsorption on the impurity, and subsequent superficial desorption.

A probability of such a mechanism is high enough, as due to the interaction of sodium and impurity atoms with electrons in the adsorption layer there is a possibility of the valence sodium electron transition into an empty impurity shell, while the bonds between sodium and chlorine in the sodium chloride molecule will be weakened.

This can lead to the sodium chloride molecule collapse resulting in the formation of chloride impurities and their subsequent evaporation. A possibility of such a mechanism is considered in $[4,5]$, where it is shown that the degree of superficial desorption of alkalinehaloid molecules significantly depends on the electronic interaction with the substrate.

It should be noted that when sodium chloride vapors condense on the surface of some elements, there is no a necessary weakening of bonds between sodium and chlorine, that ensures the $\mathrm{NaCl}$ molecule collapse and new chloride formation. Such elements include, for example, niobium, molybdenum, tungsten, carbon, etc.

The graphite powder refining by the vacuumthermal method and vacuum-thermal method with the use of a back-dissociating $\mathrm{NaCl}$ activator was carried out in compliance with identical parameters of power increasing. At the same time, the temperature in the area of the container with GAK-1 powder was changing as shown in Fig. 2.

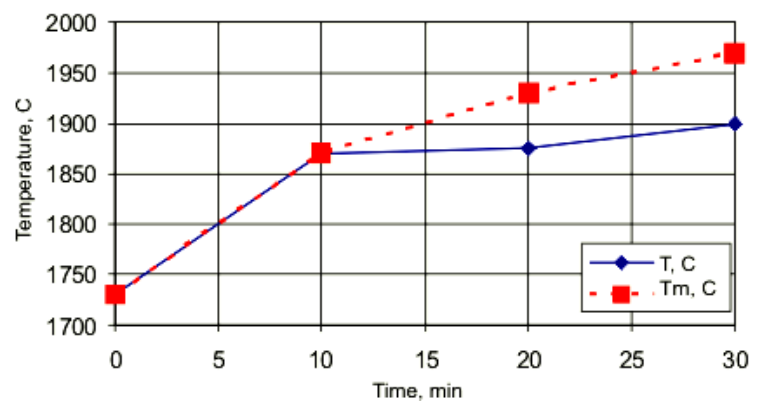

Fig. 2. Temperature curves for the graphite refining container as a function of time

(by pyrometric measurements)

Different shape of the curves at temperatures exceeding $1870^{\circ} \mathrm{C}$, with the same specific heating power in both experiments, is due to the heat removal by the $\mathrm{NaCl}$ vapors.

The efficiency of the process of graphite powder refining using different refining methods was determined by gravimetric analysis on ash; the burning of graphite powder charge was performed in the air atmosphere at $900{ }^{\circ} \mathrm{C}$, according to GOST 22692-77 [6]. The measurement results are shown in Table 2.

Table 2

The ash content in natural graphite of GAK-1 grade after refining using different methods

\begin{tabular}{|l|c|c|}
\hline \multicolumn{1}{|c|}{ Refining method } & $\begin{array}{c}\text { Graphite powder } \\
\text { charge mass, } \mathrm{g}\end{array}$ & Ash content, \% \\
\hline \multicolumn{1}{|c|}{ Initial graphite } & 137.9851 & 0.36 \\
\hline $\begin{array}{l}\text { Refining at } 1950^{\circ} \mathrm{C} \\
\text { using the vacuum- } \\
\text { thermal method }\end{array}$ & 138.0836 & 0.11 \\
\hline $\begin{array}{l}\text { Refining at } 1850^{\circ} \mathrm{C}, \\
\text { vacuum-thermal } \\
\text { method using } \\
\text { activator }(\mathrm{NaCl})\end{array}$ & 126.7696 & 0.04 \\
\hline
\end{tabular}

\section{RESULTS AND DISCUSSION}

Analysis of results shows that the use of the activator in vacuum-thermal refining makes it possible to decrease the ash content of graphite by $60 \%$, i. e. to increase the process efficiency. 
The ash content decrease by $60 \%$ in the case of $\mathrm{NaCl}$ vapors passing through the graphite powder being refined at a lower average temperature of powder (see Fig. 2), in our opinion, is due to the formation of volatile intermediate compounds with $\mathrm{NaCl}[3,7]$.

\section{CONCLUSIONS}

A new method for vacuum-thermal refining of carbon materials using sodium chloride as an activator is proposed and experimentally tested.

The experimental results confirm that that the use of such a technique can increase the efficiency of carbon refining processes by $60 \%$.

The results obtained can serve as a base for the production of domestic upgraded-purity graphite materials, which can become an alternative to imported high-purity graphite.

\section{REFERENCES}

1. V.N. Starchenko, S.I. Shevchenko, E.V. Polupan, V.A. Gurin, I.V. Gurin. New friction materials for rolling stock braking devices (Part 1) // Transmash. 2013, N 11, p. 21-23.

2. O.G. Kaplenko, I.V. Gurin, T.S. Yakovitskaya. Purity of graphite and carbon composite materials // Problems of Atomic Science and Technology. 2011, N 2, p. 132-136.

3. V.I. Zmij, S.G. Rudenky. Reaktsionnoactivirovannaya diffusiya and vakuumnyye pokrytiya. Kharkov: NSC KIPT, 2010, 158 p. (in Russian).

4. O.P. Burmistrova, N.D. Potekhina. Adsorption influence on the electron structure and bonds in the $\mathrm{NaCl}$ molecule // Poverkhnost: Fisika, Khimiya, Mekhanika. 1984, N 10, p. 65-75 (in Russian).

5. E.Ya. Zandberg, A.Ya. Tantegode, Yu.K. Yusifov. Surface ionization of $\mathrm{CsCl}$ molecules on the Jr(111)C film emitter // Zhurnal of Tekhnicheskoj Phiziki. 1972, v. 42, N 1, p. 171-175 (in Russian).

6. Carbon Materials. The method of ash content testing. GOST 22692-77.

7. G. Schaefer. Chemical transport reactions (transport of inorganic matters through a gas phase and its application). M.: "Mir", 1964, 194 p.

Article received 18.11.2019

\title{
ВАКУУМНАЯ ВЫСОКОТЕМПЕРАТУРНАЯ РАФИНАЦИЯ УГЛЕРОДНОГО МАТЕРИАЛА С ИСПОЛЬЗОВАНИЕМ ПАРОВ $\mathrm{NaCl}$ В КАЧЕСТВЕ ТРАНСПОРТНО-РЕАКЦИОННОЙ СРЕДЫ
}

\author{
Я.В. Кравцов, И.В. Гурин, А.М. Буколов, Ю.А. Грибанов, В.В. Колосенко
}

Одним из основных требований к углеродным материалам является их чистота. В работе представлена и экспериментально проверена новая методика вакуумно-термической рафинации углеродных материалов с использованием в качестве активатора $\mathrm{NaCl}$. Экспериментально подтверждено, что использование такой методики позволяет повысить эффективность и уменьшить энергоемкость процессов рафинации. Предложенная методика может стать альтернативой современным методам хлор- и фтортермической рафинации, тем самым позволит исключить использование вредных и опасных реагентов.

\section{ВАКУУМНА ВИСОКОТЕМПЕРАТУРНА РАФІНАЦІЯ ВУГЛЕЦЕВИХ МАТЕРІАЛІВ ІЗ ВИКОРИСТАННЯМ ПАРІВ NaCІ В ЯКОСТІ ТРАНСПОРТНО-РЕАКЦІЙНОГО СЕРЕДОВИЩА}

\author{
Я.В. Кравцов, І.В. Гурін, А.М. Буколов, Ю.А. Грибанов, В.В. Колосенко
}

Однією 3 основних вимог до вуглецевих матеріалів $\epsilon$ їх чистота. В роботі представлена та експериментально перевірена нова методика вакуумно-термічної рафінації вуглецевих матеріалів 3 використанням в якості активатора $\mathrm{NaCl}$. Експериментально підтверджено, що використання такої методики дозволяє підвищити ефективність та зменшити енергоємність процесів рафінації. Запропонована методика може стати альтернативою сучасним методам хлор- та фтортермічної рафінації, тим самим дозволить виключити використання шкідливих та небезпечних реагентів. 